\title{
Effect of Nano Phosphatic Fertilizer on Nutrient Content and Uptake by Pearl Millet (Pennisetum glaucum L.) Crop
}

\author{
Atul Dhansil ${ }^{1 *}$, N.M. Zalawadia ${ }^{1}$, Bhawani Singh Prajapat ${ }^{2}$ and Kamlesh Yadav ${ }^{3}$ \\ ${ }^{1}$ Department of Agriculture Chemistry \& Soil Science, College of Agriculture, JAU, \\ Junagadh, India \\ ${ }^{2}$ Department of Agronomy, ${ }^{3}$ Department of Agriculture Chemistry \& Soil Science, Rajasthan \\ College of Agriculture, MPUAT, Udaipur, India
}

*Corresponding author

\begin{tabular}{|c|c|}
\hline & A B S T R A C T \\
\hline $\begin{array}{l}\text { Ke e y w o r d s } \\
\text { Nano phosphatic } \\
\text { fertilize, Chemical } \\
\text { phosphatic } \\
\text { fertilizer, RDP, } \\
\text { Pearl millet }\end{array}$ & \multirow{3}{*}{$\begin{array}{l}\text { A study was undertaken to evaluate the efficiency of phosphatic nano fertilizer } \\
\text { under pot culture trail. The experiment was conducted during the summer } 2017 \text { to } \\
\text { know the effect of different levels of nano and chemical phosphatic fertilizer on } \\
\text { NPK nutrient (Nitrogen, phosphorus and potassium) content and uptake by pearl } \\
\text { millet crop in Vertic Ustocrepts medium black calcareous soil. The experiment } \\
\text { was containing control with seven different treatments. The pot culture study } \\
\text { showed that the application of nano and chemical phosphatic fertilizer } \\
\text { significantly increased the nutrient content and uptake by pearl millet crop. The } \\
\text { maximum NPK content and uptake as well as protein content and uptake were } \\
\text { observed with the application of } 2.5 \text { time reduction of RDP through nano } \\
\text { phosphatic fertilizer. }\end{array}$} \\
\hline Article Info & \\
\hline $\begin{array}{l}\text { Accepted: } \\
\text { 17 November } 2018 \\
\text { Available Online: } \\
10 \text { December } 2018\end{array}$ & \\
\hline
\end{tabular}

\section{Introduction}

Phosphorus $(\mathrm{P})$ is essential to all forms of life and important for its contribution towards aiding the native soil fertility and sustaining it. The economic challenges associated with increasing $\mathrm{P}$ fertilizer prices are driving the increased interest in improving $P$ use efficiency. Moreover, transfer of soil P from cultivated land through erosion or runoff is a major cause of P-induced eutrophication in surface waters. This underlines the significance of $\mathrm{P}$ management taking care of native supplies and crop demands under a given cropping system. In order to develop judicious P management options, it is essential to critically analyse the scientific knowledge pertaining to different aspects governing the availability of native and applied $P$ to the crops (Sanyal et al., 2015). The application of nano technology in fertilizer is the best alternative to increase PUE.

Nanotechnology has provided the feasibility of exploiting nanoscale or nanostructured materials as fertilizer carriers or controlled 
release of nutrients so-called "smart fertilizer" as new facilities to enhance nutrient use efficiency and reduce costs of environmental protection (Veronica et al., 2015). Nano materials are defined as materials with a single unit between 1 and $100 \mathrm{~nm}$ in size in at least one dimension (Liu and Lal, 2014) and having a both positive and negative charge on same particle that lead to improve uptake of other nutrient by holding those nutrient in soil against the different losses.

Pearl millet is the most widely cultivated millet crop, occupying a prominent position in global agriculture. Among the coarse cereals grown, pearl millet occupies pivotal position in the arid and semi-arid regions of India. The share of pearl millet in total food grain production is 10.7 per cent. India stands on first position in pearl millet production. In India pearl millet is grown in an area of 7.12 Mha with an annual production of $9.86 \mathrm{Mt}$ and a productivity of $1132 \mathrm{~kg} \mathrm{ha}^{-1}$ (Annual Report, 2016-17). Rajasthan, Maharashtra, Gujarat, Uttar Pradesh and Haryana are the important pearl millet growing states. Similarly, Gujarat ranks third in area as well as production of pearl millet. In Gujarat, pearl millet is grown in an area of 0.67 lakh hectare and producing 1.02 lakh tones annually.

Many soils of the semi-arid tropics are deficient in $\mathrm{P}$, and under such adverse conditions, the establishment of pearl millet seedlings is a critical step to achieve satisfactory crop stands. Phosphorus fertilizer is expensive for small holder farmers and low phosphorus use efficiency was observed under dry land condition that make phosphorus unavailable to pearl millet for satisfactory crop stands (Valluru et al., 2008). To increase phosphorus use efficiency and minimize the losses of phosphatic fertilizers, nano phosphatic fertilizer is the best alternative to increase phosphorus use efficiency as well as other nutrient and protein content. Nano fertilizer increases fertilizer use efficiency by targeted release of nutrient in adequate proportion without any harmful effect on soil as well as plant (Rameshaiah et al., 2015).

\section{Materials and Methods}

The nano particle prepare by using blank chitosan particle which size vary from 1 to $100 \mathrm{~nm}$. The experiment was conducted in net house of biotechnology department, college of agriculture, JAU, Junagadh (Gujarat), India. The design of the experiment was a complete randomized block with three replications. They were seven treatments included $\left(\mathrm{T}_{1}=\right.$ Absolute control (No fertilizer), $\mathrm{T}_{2}=$ Nano polymer, $\mathrm{T}_{3}=\mathrm{RDP}$ of pearl millet crop through chemical fertilizer, $\mathrm{T}_{4}=\mathrm{NP}_{2.5}-2.5$ times reduction of RDP through nano fertilizer, $\mathrm{T}_{5}=\mathrm{NP}_{5}-5$ times reduction of RDP through nano fertilizer, $\mathrm{T}_{6}=\mathrm{NP}_{10}-10$ times reduction of RDP through nanofertilizer, $\mathrm{T}_{7}=$ RDP through nano fertilizer) by using two different sources of fertilizer (SSP as a chemical fertilizer-16 $\% \quad \mathrm{P}_{2} \mathrm{O}_{5}$, Nano $\mathrm{P}$ fertilizer-16 $\% \mathrm{P}_{2} \mathrm{O}_{5}$ ). The basal dose of nitrogen and potassium apply at the time of sowing by neem coated urea and MOP @ of 80 and $40 \mathrm{~kg}$ respectively. The physicochemical properties of soil are presented in table 1.

\section{Results and Discussion}

Effect of different levels of nano and chemical phosphatic fertilizers on nitrogen content and it's uptake by grain and straw

The data presented in table 2 revealed that the different levels of nano and chemical phosphatic fertilizer on protein content $(\%)$ and protein yield $\left(\mathrm{g} \mathrm{pot}^{-1}\right)$ of pearl millet crop. The protein content $(\%)$ was significantly increased from 8.65 to $10.67 \%$ under different level of chemical and nano phosphatic fertilizer. The significantly highest 
protein content $(10.67 \%)$ was observed with the application of 2.5 time reduction of RDP through nano fertilizer $\left(\mathrm{T}_{4}\right.$ treatment). But it was statistically at par with $\mathrm{T}_{7}$ treatment @ of RDP through nano fertilizer. The lowest protein content $(8.65 \%)$ was observed under control treatment $\left(\mathrm{T}_{1}\right)$ and it was remained statistically at par with treatment of $\mathrm{T}_{2}(9.13$ $\%)$. While, the treatment of $\mathrm{T}_{3} @$ of RDP through chemical fertilizer produced significantly higher protein content $(9.79 \%)$ followed by $\mathrm{T}_{5}(9.79)$ and $\mathrm{T}_{6}(9.40 \%)$ treatment but lower than $\mathrm{T}_{4}$ and $\mathrm{T}_{7}$ treatment. The treatment $\mathrm{T}_{5}$ and $\mathrm{T}_{6}$ were remained statistically at par with each other. The similar trend was also observed in case of protein yield.

The application of 2.5 time reduction of RDP through nano fertilizer produced higher protein content and protein yield as compared to remaining treatments. This is due to control and steady release property of nano phosphatic fertilizer that balancing and increasing the nitrogen content and uptake by plant, which resulted in improved protein content in plants. Van et al., (2013) observed that the application of chitosan nano particles showed positive relationship between nitrogen and phosphorus uptake by coffee plant. These results are supported by the earlier work of Soliman et al., (2016), they observed that the success of nHA fertilizer (hydroxyapatite nanoparticle) may be due to greater density in reactive areas which increased the uptake of nitrogen that eventually led to enhance in leaf moisture percentage, total chlorophyll, crude protein, total carbohydrate and plant nutrients. Amirnia et al., (2014) reported that application of nanoparticles in a number of crops has evidenced for enhanced physiological activities, gene expression and protein level indicating their potential use in crop improvement. The similar results are lined by Rane et al., (2015), Hasaneen et al., (2016) and Celsia and Mala (2014).
The results summarized in table 2 indicated that different levels of nano and chemical phosphatic fertilizer produce significant effect on nitrogen content and uptake by straw. The nitrogen content increased in straw from 0.44 to 0.75 per cent under different levels of nano and chemical phosphatic fertilizer. The application of $\mathrm{T}_{4}$ treatment @ of 2.5 time reduction of RDP through nano fertilizer produced significantly highest nitrogen content $(0.75 \%)$ in straw followed by $\mathrm{T}_{7}, \mathrm{~T}_{3}$, $\mathrm{T}_{5}$ and $\mathrm{T}_{6}$ treatments, out of these treatments. $\mathrm{T}_{7}(0.70 \%)$ treatment was remain statistically at par with each other. The lowest $(0.44 \%) \mathrm{N}$ content was observed with control, but it was statistically at par with treatment $\mathrm{T}_{2}(0.48 \%)$. While the treatment of $\mathrm{T}_{3}$ (RDP through chemical fertilizer) produce significantly higher $(0.62 \%)$ nitrogen content in straw followed by $\mathrm{T}_{5}(0.60 \%)$ and $\mathrm{T}_{6}(0.54 \%)$ treatment but remain lower than $\mathrm{T}_{4}(0.75 \%)$ and $\mathrm{T}_{7}(0.70 \%)$ treatment. The same trend was also observed in case of nitrogen uptake by straw. However, the effect of different levels of phosphatic fertilizer on nitrogen content and uptake was found significant. The maximum (0.91 $\left.\mathrm{g} \mathrm{pot}^{-1}\right)$ nitrogen uptake by straw was observed under $\mathrm{T}_{4}$ treatment @ 2.5 time reduction of RDP through nano fertilizer. While, the lowest $\left(0.37 \mathrm{~g} \mathrm{pot}^{-1}\right)$ nitrogen uptake by straw was observed under control treatment.

The nitrogen content in grain was significantly affected by different levels of nano and chemical phosphatic fertilizer. The significantly highest $(1.71 \%)$ nitrogen content was observed under $\mathrm{T}_{4}$ treatment @ 2.5 time reduction of RDP through nano fertilizer, which was statistically at par with $\mathrm{T}_{7}$ treatment (1.66\%) @ of RDP through nano fertilizer. While, the lowest $(1.38 \%)$ nitrogen content was observed under control $\left(\mathrm{T}_{1}\right.$ treatment) and it was statistically at par with treatment $\mathrm{T}_{2}(1.46 \%)$. The treatment $\mathrm{T}_{3} @$ of RDP through chemical fertilizer produced 
significantly higher nitrogen content $(1.57 \%)$ followed by $\mathrm{T}_{5}(1.57 \%)$ and $\mathrm{T}_{6}(1.50 \%)$ treatments but lower than the $\mathrm{T}_{4}(1.71 \%)$ and $\mathrm{T}_{7}(1.66 \%)$ treatments. The similar trend was also observed with nitrogen uptake by grain. The maximum (1.05 $\left.\mathrm{g} \mathrm{pot}^{-1}\right)$ nitrogen uptake by grain was observed under $\mathrm{T}_{4}$ treatment @ 2.5 time reduction of RDP through nano fertilizer. But it was statistically at par with $\mathrm{T}_{7}$ $(0.95 \%)$ treatment. While, the lowest $(0.52 \mathrm{~g}$ pot $^{-1}$ ) nitrogen uptake by grain was observed under control. The data conclusively demonstrates that total nitrogen uptake significantly affected by application of nano fertilizer. The total nitrogen uptake significantly increased from 0.89 to $1.96 \mathrm{~g}$ $\operatorname{pot}^{-1}$. The significantly highest total nitrogen uptake (1.96 $\left.\mathrm{g} \mathrm{pot}^{-1}\right)$ was observed in $\mathrm{T}_{4}$ treatment @ 2.5 time reduction of RDP through nano fertilizer. The lowest total nitrogen uptake $\left(0.89 \mathrm{~g} \mathrm{pot}^{-1}\right)$ was observed with control. This may be due to fertilizer particles can be coated with nano membranes that facilitate slow and steady release of nutrients. Coating and cementing of nano and sub nano-composites are capable of regulating the release of nutrients from the fertilizer capsule and nano particles having both positive and negative charged binding site that adsorbed available nitrogen in soil to minimize different type losses resulted in increased uptake of nitrogen by crop. This results are agreed by Hussien et al., (2015). They observed that application of nano-P at the rate of $1.0 \mathrm{~g} \mathrm{l}^{-1}$ achieved the highest values of nutrients uptake (N, P, K and micro nutrient) in leaves of cotton plants. Soliman et al., (2016) reported that the positive interaction occurs between phosphorus and nitrogen that indicate that the nitrogen uptake was increased with increasing uptake of phosphorus. Singh et al., (2017) observed that highest $\mathrm{N}$ content and uptake was recorded with the treatment of $30 \mathrm{~kg} \mathrm{P} \mathrm{ha}^{-1}$ applied. The increase in availability of soil nutrients might be due to the inorganic fertilization process to soil and mineralization and solubilization of available nutrients through direct and indirect mechanism of nutrients in soil and transport of nutrients to plant. These observations are in conformity with those reported by Hussien et al., (2015), Guru et al., (2015) and Kaviani et al., (2016).

\section{Effect of different levels of nano and chemical phosphatic fertilizers on phosphorus content and it's uptake by pearl millet crop}

The data furnished in table 3 indicated that different levels of nano and chemical phosphatic fertilizer produced significant effect on phosphorus content and its uptake by straw. The phosphorus content was increased in straw from 0.12 to 0.25 per cent under different levels of nano and chemical phosphatic fertilizer. The significantly highest phosphorus content $(0.25 \%)$ in straw was observed under $\mathrm{T}_{4}$ treatment @ of 2.5 time reduction of RDP through nano fertilizer, followed by $\mathrm{T}_{7}, \mathrm{~T}_{5}, \mathrm{~T}_{3}$ and $\mathrm{T}_{6}$ treatments, out of these treatment of $\mathrm{T}_{7}(0.23 \%)$ was remained statistically at par with each other.

The lowest phosphorus content $(0.12 \%)$ was observed with control, but it was statistically at par with treatment $\mathrm{T}_{2}(0.14 \%)$. While the treatment $\mathrm{T}_{3}$ (RDP through chemical fertilizer) produced significantly higher $(0.18 \%)$ phosphorus content in straw followed by $\mathrm{T}_{6}$ $(0.16 \%)$ treatment but remained lower than $\mathrm{T}_{4}$ $(0.25 \%)$ and $\mathrm{T}_{7}(0.23 \%)$ treatment. The same trend was also observed in case of phosphorus uptake by straw. The effect of different levels of phosphatic fertilizer on phosphorus content and uptake was found significant. The maximum ( $\left.0.30 \mathrm{~g} \mathrm{pot}^{-1}\right)$ phosphorus uptake by straw was observed under $\mathrm{T}_{4}$ treatment @ 2.5 time reduction of RDP through nano fertilizer. While, the lowest $\left(0.10 \mathrm{~g} \mathrm{pot}^{-1}\right)$ phosphorus uptake by straw was observed under control. 
The phosphorus content in grain was significantly affected by different levels of nano and chemical phosphatic fertilizer. The significantly highest $(0.44 \%)$ phosphorus content was observed under $\mathrm{T}_{4}$ treatment @ 2.5 time reduction of RDP through nano fertilizer, which was statistically at par with $\mathrm{T}_{7}$ treatment $(0.41 \%)$ @ of RDP through nano fertilizer. While, the lowest $(0.24 \%)$ phosphorus content was observed under control ( $\mathrm{T}_{1}$ treatment) and it was statistically at par with treatment $\mathrm{T}_{2}(0.28 \%)$. The treatment $\mathrm{T}_{3} @$ of RDP through chemical fertilizer produced significantly higher phosphorus content $(0.37 \%)$ followed by $\mathrm{T}_{5}$ $(0.35 \%)$ and $\mathrm{T}_{6}(0.31 \%)$ treatments but lower than the $\mathrm{T}_{4}(0.44 \%)$ and $\mathrm{T}_{7}(0.41 \%)$ treatments. The similar trend was also observed with phosphorus uptake by grain. The maximum $\left(0.27 \mathrm{~g}\right.$ pot $\left.^{-1}\right)$ phosphorus uptake by grain was observed under $\mathrm{T}_{4}$ treatment @2.5 time reduction of RDP through nano fertilizer. While, the lowest $\left(0.09 \mathrm{~g} \mathrm{pot}^{-1}\right)$ phosphorus uptake by grain was observed under control. The cumulative data of total phosphorus uptake significantly affected by application of nano and chemical phosphatic fertilizer. The total phosphorus uptake was significantly increased from 0.19 to $0.57 \mathrm{~g} \mathrm{pot}^{-1}$. The significantly highest total phosphorus uptake $\left(0.57 \mathrm{~g} \mathrm{pot}^{-1}\right)$ was observed in $\mathrm{T}_{4}$ treatment@ 2.5 time reduction of RDP through nano fertilizer. The lowest total phosphorus uptake $\left(0.19 \mathrm{~g} \mathrm{pot}^{-1}\right)$ was observed with control ( $T_{1}$ treatment). The reason behind this the nanohydroxyapatite (nHA) particles having diameters of $25-50 \mathrm{~nm}$ which led to increase total surface area to retain $\mathrm{P}$ and protect phosphorus from fixation by $\mathrm{Fe} / \mathrm{Al} / \mathrm{Ca}$ resulted in making more available phosphorus for longer time due to control release of nutrient and increased uptake of phosphorus. The results are in conformity with Mikhak et al., (2016). They observed that saturated nano zeolite with ammonium sulfate based on dissolution and ion-exchange reactions, can increase $\mathrm{P}$ solubility in calcareous soils due to decreasing the soil $\mathrm{pH}$ and adsorbing its calcium. Overall, the slow and steady release of $\mathrm{P}$ allows plants to continuously take up nutrients as they grown. Sarkar et al., (2013) observed that application of NCPC-H (nano phosphatic fertilizer) significantly increased the $\mathrm{P}$ concentration $(0.112 \%)$ and $\mathrm{P}$ uptake (32.4 $\mathrm{mg} \mathrm{pot}^{-1}$ ) by pearl millet. The NCPC addition (NCPC-H) registered $42 \%$ additional $\mathrm{P}$ uptake by pearl millet over $\mathrm{CF}(\mathrm{CF}-\mathrm{H})$. Hanif et al., (2015) reported that the P uptake per plant was increased five-folds with reference to the control. This may be due to the entry of nanoparticles in plant can trigger metabolic activity contributing and enhanced exudation leading to acidification. Subsequently, desorption of $\mathrm{PO}_{4}{ }^{3-}$ could occur through a ligand exchange reaction upon plant root exudation, possibly altering the adsorption desorption equilibrium and releasing $\mathrm{P}$ into soil solution which is readily available for uptake. Hussien et al., (2015) observed that synthetic apatite nano-particles could hypothetically supply sufficient $\mathrm{P}$ nutrients to crops throughout the growing period. The results are lined by Kaviani et al., (2016), Soliman et al., (2016), Rajonee et al., (2017) and Togas et al., (2017).

\section{Effect of different levels of nano and chemical phosphatic fertilizers on potassium content and it's uptake by pearl millet}

The data in table 4 indicated that the application of different levels of nano and chemical phosphatic fertilizer on nutrient content and its uptake by straw. The potassium content was increased in straw from 0.35 to 0.69 per cent under different levels of nano and chemical phosphatic fertilizer. The significantly highest potassium content (0.69 $\%$ ) in straw was observed under $\mathrm{T}_{4}$ treatment @ of 2.5 time reduction of RDP through nano fertilizer, but it was remained statistically at 
par with the treatment of $\mathrm{T}_{7}(0.64 \%)$. The lowest phosphorus content $(0.35 \%)$ was observed with control. While, the treatment $\mathrm{T}_{3} \quad$ (RDP through chemical fertilizer) produced significantly higher $(0.56 \%)$ potassium content in straw followed by $\mathrm{T}_{5}$ $(0.54 \%)$ and $\mathrm{T}_{6}(0.48 \%)$ treatment but remained lower than $\mathrm{T}_{4}(0.69 \%)$ and $\mathrm{T}_{7}(0.64$
\%) treatment. The similar trend was also observed in case of potassium uptake by straw. The maximum $\left(0.84 \mathrm{~g} \mathrm{pot}^{-1}\right)$ potassium uptake by straw was observed under $\mathrm{T}_{4}$ treatment @2.5 time reduction of RDP through nano fertilizer. While, the lowest $\left(0.30 \mathrm{~g} \mathrm{pot}^{-1}\right)$ potassium uptake by straw was observed under control.

Table.1 Pysico-chemical properties of the experimental soil

\begin{tabular}{|c|c|c|}
\hline Particular & $\begin{array}{l}\text { Value at soil depth } \\
\qquad(\mathbf{0 - 2 0} \mathbf{~ c m})\end{array}$ & Method followed \\
\hline \multicolumn{3}{|l|}{ A. Mechanical Composition } \\
\hline 1. Sand $\%$ & 15.01 & \multirow{4}{*}{$\begin{array}{l}\text { International Pipette method (Piper, } \\
\text { 1950) }\end{array}$} \\
\hline 2. Silt \% & 28.96 & \\
\hline 3. Clay \% & 56.03 & \\
\hline 4. Texture class & Clayey & \\
\hline \multicolumn{3}{|l|}{ B. Chemical Composition } \\
\hline 1. Soil pH $(1: 2.5)$ & 8.0 & pH meter (Richard, 1954) \\
\hline $\begin{array}{l}\text { 2. Electrical Conductivity } \\
(\mathrm{dS} / \mathrm{m}) \text { at } 25^{\circ} \mathrm{C}(1: 2.5)\end{array}$ & 0.58 & $\begin{array}{l}\text { EC meter } \\
(\text { Jackson, 1974) }\end{array}$ \\
\hline 3. Organic Carbon $\left(\mathrm{g} \mathrm{kg}^{-1}\right)$ & 6.6 & $\begin{array}{l}\text { Walkley and Black's method (Jackson, } \\
\text { 1974) }\end{array}$ \\
\hline 4. $\mathrm{CaCO}_{3} \%$ & 31.05 & $\begin{array}{l}\text { Rapid acid neutralize method } \\
\text { (Piper,1950) }\end{array}$ \\
\hline 5. CEC : C mol $\left(p^{+}\right) k^{-1}$ & 36.2 & $\begin{array}{l}\text { Neutral normal ammonium acetate } \\
\text { method (Black,1965) }\end{array}$ \\
\hline 6. Available N $\left(\mathrm{kg} \mathrm{ha}^{-1}\right)$ & 242.00 & $\begin{array}{l}\text { Alkaline } \mathrm{KMnO}_{4} \text { method (Subbaiah and } \\
\text { Asija, 1956) }\end{array}$ \\
\hline 7.Available $\mathrm{P}_{2} \mathrm{O}_{5}\left(\mathrm{~kg} \mathrm{ha}^{-1}\right)$ & 39.20 & $\begin{array}{l}\text { Olsen's method } \\
\text { (Olsen } \text { et. al., 1954) }\end{array}$ \\
\hline 8. Available $\mathrm{K}_{2} \mathrm{O}\left(\mathrm{kg} \mathrm{ha}^{-1}\right)$ & 298.00 & $\begin{array}{l}\text { Flame photometric method (Jackson, } \\
\text { 1974) }\end{array}$ \\
\hline 9. Available $S\left(\mathrm{~kg} \mathrm{ha}^{-1}\right)$ & 29.50 & $\begin{array}{l}\text { Turbid metric method (Chaudhary and } \\
\text { Cornfield,1966) }\end{array}$ \\
\hline 10. Available $\mathrm{Fe}\left(\mathrm{mg} \mathrm{kg}^{-1}\right)$ & 3.25 & \multirow{4}{*}{$\begin{array}{l}\text { DTPA extract method (Lindsay and } \\
\text { Norvell, 1978) }\end{array}$} \\
\hline 11. Available $\mathrm{Zn}\left(\mathrm{mg} \mathrm{kg}^{-1}\right)$ & 0.55 & \\
\hline 12. Available $\mathrm{Mn}\left(\mathrm{mg} \mathrm{kg}^{-1}\right)$ & 5.20 & \\
\hline 13. Available $\mathrm{Cu}\left(\mathrm{mg} \mathrm{kg}^{-1}\right)$ & 1.25 & \\
\hline
\end{tabular}


Table.2 Effect of different levels of nano and chemical phosphatic fertilizers on quality parameter, nitrogen content and it's uptake by pearl millet

\begin{tabular}{|c|c|c|c|c|c|c|c|}
\hline \multirow[t]{2}{*}{ Treatments } & \multicolumn{2}{|c|}{$\begin{array}{l}\text { Nitrogen content } \\
(\%)\end{array}$} & \multicolumn{2}{|c|}{$\begin{array}{l}\text { Nitrogen uptake } \\
\qquad\left(\mathrm{g} \mathrm{pot}^{-1}\right)\end{array}$} & \multirow{2}{*}{$\begin{array}{c}\text { Total } \\
\text { nitrogen } \\
\text { uptake } \\
\left(\mathrm{g} \mathrm{pot}^{-1}\right)\end{array}$} & \multicolumn{2}{|c|}{ Quality parameter } \\
\hline & Grain & Straw & Grain & Straw & & $\begin{array}{c}\text { Protein content } \\
\qquad(\%)\end{array}$ & $\begin{array}{l}\text { Protein yield } \\
\qquad\left(\text { g pot }^{-1}\right)\end{array}$ \\
\hline $\mathbf{T}_{1}=$ Absolute control (No fertilizer) & 1.38 & 0.44 & 0.52 & 0.37 & 0.89 & 8.65 & 3.26 \\
\hline$T_{2}=$ Nano polymer & 1.46 & 0.48 & 0.63 & 0.44 & 1.06 & 9.13 & 3.91 \\
\hline $\begin{array}{c}T_{3}=\text { RDP of pearl millet crop } \\
\text { through chemical fertilizer }\end{array}$ & 1.57 & 0.62 & 0.81 & 0.66 & 1.47 & 9.79 & 5.04 \\
\hline $\begin{array}{c}\mathrm{T}_{4}=\mathrm{NP}_{2.5}-2.5 \text { times reduction of } \\
\text { RDP through nano fertilizer }\end{array}$ & 1.71 & 0.75 & 1.05 & 0.91 & 1.96 & 10.67 & 6.57 \\
\hline $\begin{aligned} \mathrm{T}_{5}= & \mathrm{NP}_{5}-5 \text { times reduction of } \mathrm{RDP} \\
& \text { through nano fertilizer }\end{aligned}$ & 1.57 & 0.60 & 0.80 & 0.62 & 1.42 & 9.79 & 5.01 \\
\hline $\begin{array}{c}\mathbf{T}_{6}=\mathrm{NP}_{10}-10 \text { times reduction of } \\
\text { RDP through nano fertilizer }\end{array}$ & 1.50 & 0.54 & 0.72 & 0.51 & 1.23 & 9.40 & 4.47 \\
\hline$T_{7}=$ RDP through nano fertilizer & 1.66 & 0.70 & 0.95 & 0.82 & 1.77 & 10.35 & 5.93 \\
\hline S.Em. \pm & 0.05 & 0.02 & 0.03 & 0.02 & 0.04 & 0.28 & 0.21 \\
\hline C.D. at $5 \%$ & 0.14 & 0.06 & 0.10 & 0.07 & 0.14 & 0.86 & 0.64 \\
\hline C.V. $\%$ & 5.05 & 5.78 & 7.48 & 6.63 & 5.52 & 5.05 & 7.48 \\
\hline
\end{tabular}


Table.3 Effect of different levels of nano and chemical phosphatic fertilizers on phosphorus contents and it's uptake by pearl millet

\begin{tabular}{|c|c|c|c|c|c|}
\hline \multirow[t]{2}{*}{ Treatments } & \multicolumn{2}{|c|}{$\begin{array}{c}\text { Phosphorus } \\
\text { content } \\
(\%)\end{array}$} & \multicolumn{2}{|c|}{$\begin{array}{c}\text { Phosphorus } \\
\text { uptake } \\
\left(\mathrm{g} \mathrm{pot}^{-1}\right)\end{array}$} & \multirow{2}{*}{$\begin{array}{c}\text { Total } \\
\text { phosphorus } \\
\text { uptake } \\
\left(\mathrm{g} \mathrm{pot}^{-1}\right)\end{array}$} \\
\hline & Grain & Straw & Grain & Straw & \\
\hline$T_{1}=$ Absolute control (No fertilizer) & 0.24 & 0.12 & 0.09 & 0.10 & 0.19 \\
\hline$T_{2}=$ Nano polymer & 0.28 & 0.14 & 0.12 & 0.13 & 0.25 \\
\hline $\begin{array}{c}T_{3}=\text { RDP of pearl millet crop through } \\
\text { chemical fertilizer }\end{array}$ & 0.37 & 0.18 & 0.19 & 0.19 & 0.38 \\
\hline $\begin{aligned} & \mathrm{T}_{4}= \mathrm{NP}_{2.5}-2.5 \text { times reduction of } \mathrm{RDP} \\
& \text { through nano fertilizer }\end{aligned}$ & 0.44 & 0.25 & 0.27 & 0.30 & 0.57 \\
\hline 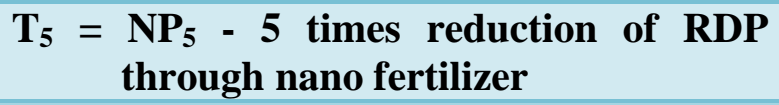 & 0.35 & 0.19 & 0.18 & 0.20 & 0.38 \\
\hline 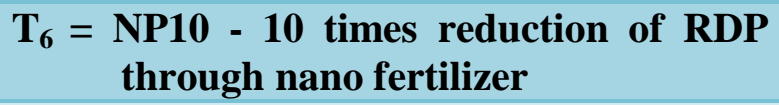 & 0.31 & 0.16 & 0.15 & 0.15 & 0.30 \\
\hline $\mathbf{T}_{7}=$ RDP through nano fertilizer & 0.41 & 0.23 & 0.24 & 0.27 & 0.50 \\
\hline S.Em. \pm & 0.01 & 0.01 & 0.01 & 0.01 & 0.01 \\
\hline C.D. at $5 \%$ & 0.04 & 0.02 & 0.02 & 0.03 & 0.04 \\
\hline C.V. $\%$ & 6.15 & 6.71 & 6.93 & 9.50 & 5.50 \\
\hline
\end{tabular}

NP - Nano fertilizer

RDP - Recommended dose of fertilizer

Table.4 Effect of different levels of nano and chemical phosphatic fertilizers on potassium content and it's uptake by pearl millet

\begin{tabular}{|c|c|c|c|c|c|}
\hline \multirow[t]{2}{*}{ Treatments } & \multicolumn{2}{|c|}{$\begin{array}{l}\text { Potassium } \\
\text { content }(\%)\end{array}$} & \multicolumn{2}{|c|}{$\begin{array}{l}\text { Potassium } \\
\text { uptake }\left(\mathrm{g} \mathrm{pot}^{-1}\right)\end{array}$} & \multirow{2}{*}{$\begin{array}{c}\text { Total } \\
\text { potassium } \\
\text { uptake }\left(\mathrm{g} \mathrm{pot}^{-1}\right)\end{array}$} \\
\hline & Grain & Straw & Grain & Straw & \\
\hline$T_{1}=$ Absolute control (No fertilizer) & 1.10 & 0.35 & 0.41 & 0.30 & 0.71 \\
\hline$T_{2}=$ Nano polymer & 1.20 & 0.43 & 0.51 & 0.39 & 0.90 \\
\hline $\begin{array}{l}T_{3}=\begin{array}{l}\text { RDP of pearl millet crop through } \\
\text { chemical fertilizer }\end{array}\end{array}$ & 1.41 & 0.56 & 0.73 & 0.60 & 1.33 \\
\hline $\begin{aligned} & \mathrm{T}_{4}= \mathrm{NP}_{2.5}-2.5 \text { times reduction of } \mathrm{RDP} \\
& \text { through nano fertilizer }\end{aligned}$ & 1.63 & 0.69 & 1.00 & 0.84 & 1.84 \\
\hline$T_{5}=\begin{array}{l}\text { NP5 }-5 \text { times reduction of RDP } \\
\text { through nano fertilizer }\end{array}$ & 1.39 & 0.54 & 0.71 & 0.55 & 1.26 \\
\hline $\begin{aligned} & T_{6}= N_{10}-10 \text { times reduction of RDP } \\
& \text { through nano fertilizer }\end{aligned}$ & 1.30 & 0.48 & 0.62 & 0.46 & 1.08 \\
\hline$T_{7}=$ RDP through nano fertilizer & 1.58 & 0.64 & 0.90 & 0.75 & 1.65 \\
\hline S.Em. \pm & 0.04 & 0.02 & 0.03 & 0.03 & 0.04 \\
\hline C.D. at $5 \%$ & 0.11 & 0.06 & 0.10 & 0.08 & 0.12 \\
\hline C.V.\% & 4.70 & 6.41 & 7.80 & 7.92 & 5.64 \\
\hline
\end{tabular}

NP - Nano fertilizer

RDP - Recommended dose of fertilizer 
A significant increase in potassium content in grain was observed under different levels of nano and chemical phosphatic fertilize (Table 4). The significant increase in potassium content was observed from 1.10 to 1.63 per cent. The significantly highest $(0.1 .63 \%)$ potassium content was observed under $\mathrm{T}_{4}$ treatment @ 2.5 time reduction of RDP through nano fertilizer, which was statistically at par with $\mathrm{T}_{7}$ treatment (1.58\%) @ of RDP through nano fertilizer. While, the lowest $(1.10 \%)$ potassium content was observed under control ( $T_{1}$ treatment) and it was statistically at par with treatment $\mathrm{T}_{2}(1.20 \%)$. The treatment $\mathrm{T}_{3} @$ of RDP through chemical fertilizer produced significantly higher potassium content $(1.41 \%)$ followed by $\mathrm{T}_{5}$ $(1.39 \%)$ and $\mathrm{T}_{6}(1.30 \%)$ treatments but lower than the $\mathrm{T}_{4}(1.63 \%)$ and $\mathrm{T}_{7}(1.58 \%)$ treatments. The similar trend was also observed with potassium uptake by grain. The maximum (1.00 $\left.\mathrm{g} \mathrm{pot}^{-1}\right)$ potassium uptake by grain was observed under $\mathrm{T}_{4}$ treatment @ 2.5 time reduction of RDP through nano fertilizer. While, the lowest $\left(0.41 \mathrm{~g} \mathrm{pot}^{-1}\right)$ potassium uptake by grain was observed under control. The data of total potassium uptake was significantly affected by application of nano and chemical phosphatic fertilizer. The total potassium uptake was significantly increased from 0.71 to $1.84 \mathrm{~g} \mathrm{pot}^{-1}$.

The significantly highest total potassium uptake (1.84 $\mathrm{g} \mathrm{pot}^{-1}$ ) was observed in $\mathrm{T}_{4}$ treatment@2.5 time reduction of RDP through nano fertilizer. The lowest total potassium uptake $\left(0.71 \mathrm{~g} \mathrm{pot}^{-1}\right)$ was observed with control ( $T_{1}$ treatment). This may be due to positive interaction between phosphorus and potassium observed by Rajonee et al., (2017). It may be due to the better release and uptake of potassium from nano fertilizer than conventional fertilizer. Soliman et al., (2016) concluded that the application of nHA (nano phosphatic fertilizer) may expose the plant nutrient (NPK) to larger surface area than can enhance the fixation of plant nutrient of nano particle which led to minimize the losses and its will release on later stage of crop growth when plant need it. Kaviani et al., (2016) observed that foliar application of nanofertilizer had significant positive effects on the leaf $\mathrm{N}, \mathrm{P}, \mathrm{K}$ contents compared with control. These results are in conformity with Buerkert et al., (1998), Kumar et al., (2014) and Shrivastava et al., (2017).

Based on the results summarized above, it can be concluded that, application of nano phosphatic fertilizer significant increase in content and uptake of nutrients. The available nitrogen and phosphorus status in post harvest soil were higher in nano fertilizer treated soil than chemical fertilizer added soil. This study clearly indicated that the application of nano fertilizer can be saved about $40 \%$ of recommended phosphatic fertilizer dose in pearl millet crop. Thus, the application of nano phosphatic fertilizer increased the phosphorus use efficiency to a considerable extent. This may be due to the fact that it control the release of phosphorus steadily for longer time as per the requirement of crop.The application of nano fertilizer improved the quality parameter like crude protein content in the grain of pearl millet crop.

\section{Acknowledgements}

The authors gratefully acknowledge the department of agricultural chemistry and soil science, college of agriculture, Junagadh Agricultural University, Junagadh (Gujarat), India for the support for the research work. We also thank for the help rendered by Dr. B. A. Golkiya, professor and head, department of biotechnology, JAU, Junagadh for technical support.

\section{References}

Amirnia, R., Bayat, M. and Tajbakhsh, M. 2014. Effects of nano fertilizer 
application and maternal corm weight on flowering of some saffron (Crocus sativus L.) ecotypes. Turk. J. Field Crops, 19(2): 158-168.

Annual Report 2016-17. Ministry of Agriculture, Govt. of India. Available at http://agricoop.nic.in/annual-report> accessed 3 Oct., 2017

Black, C. A. 1965. Cation exchange capacity. American Society of Agronomy, 10(1): $891-900$.

Buerkert, A., Haake, C., Ruckwied, M. and Marschner, H. 1998. Phosphorus application affects the nutritional quality of millet grain in the Sahel. Field Crops Res., 57: 223-235.

Celsia, A. S. R. and Mala, R. 2014. Fabrication of nano structured slow release fertilizer system and its influence on germination and biochemical characteristics of Vigna raidata. Int. J.ChemTech Res., 6(10): 4497-4503.

Chaudhary, I. A. and Cornfield, A. H. 1966. The determination of total sulphur in soil and plant materials. Analyst, 91: 528.

Guru, T., Veronica, N., Thatikunta, N. and Reddy, S. 2015. Crop nutrition management with nano fertilizers. Int. J. Environ. Sci. Tech., 1(1): 4-6.

Hanif, H. U., Arshad, M., Ali, M. A., Ahmed, N. and Qazi, I. A. 2015. Phytoavailability of phosphorus to Lactuca sativa in response to soil applied $\mathrm{TiO}_{2}$ nanoparticles. Pak. J. Agric. Sci., 52(1): 177-182.

Hasaneen, M. N. A. G., Abdel-aziz, H. M. M. and Omer, A. M. 2016. Effect of foliar application of engineered nanomaterials: carbon nanotubes NPK and chitosan nanoparticles NPK fertilizer on the growth of French bean plant. Biochem. Biotechn. Res., 4(4): 68-76.

Hussien, M. M; Soad, M. E. A. and Haggag,
W. M. 2015.Response of mineral status to nano-fertilizer and moisture stress during different growth stages of cotton plants. Int. J. ChemTech Res., 8(12): $643-650$.

Jackson, M. L. 1974. Soil Chemical Analysis. Prentice Hall of India Pvt. Ltd., New Delhi, pp. 327-350.

Kaviani, B., Ghaziani, M. V. F. and Negahdar, N. 2016. Effect of application methods and different concentrations of biologic nanofertilizer, especial for ornamental plants on some morphological, physiological and proliferation traits and enhancing the quality of buxushyrcanapojark. Int. J. Adv. Sci. Eng. Tech., Spl. Issue-2: 206 -212 .

Kumar, P., Singh, R., Singh, A., Paliwal, D. and Kumar, S. 2014. Integrated nutrient management in pearl millet (Pennisetum glaucum) - wheat (Triticum aestivum) cropping sequence in semi arid condition of India. Int. J. Agric. Sci., 10(1): $96-101$.

Lindsay, W. L. and W.A. Norvell. 1978. Development of a DTPA soil test for zinc, iron, manganese and copper. Soil Sci. Soc. Am. J., 42: 421-428.

Liu, R. and Lal, R. 2014. Synthetic apatite nanoparticles as a phosphorus fertilizer for soybean (Glycine max). Environ. Chem. Environ. Sci., 4: 1-18.

Mikhak, A., Sohrabia, A., Kassaeeb, M. Z. and Feiziana, M. 2016. Synthetic nanozeolite/nanohydroxyapatite as a phosphorus fertilizer for German chamomile (Matricaria chamomilla L.). Ind. Crops Prod., 95: 444 - 452.

Olsen, R., Watanable, P. S. and Dean, L. A. 1954. Estimation of available phosphorus in soil by extraction with sodium bicarbonate. USDA Circular No. 939.

Piper, C. S. 1950. Soil and Plant analysis. International Science Publisher, New 
York.

Rameshaiah, G. N., Pallavi, J. and Shabnam, S. 2015. Nano fertilizers and nano sensors-An attempt for developing smart agriculture. Int. J. Eng. Res. Gen. Sci., 3(1): 2091-2730.

Rane, M., Bawskar, M., Rathod, D., Nagaonkar, D. and Rai, M. 2015. Influence of calcium phosphate nanoparticles, Piriformospora indica and Glomus mosseae on growth of Zea mays. Viet. Acad. Sci. Tech., 6: 1-8.

Richard, L. A. 1954. Diagnosis and improvement of saline and alkaline soils. Hand Book No. 60, Oxford and IBH Publishing Co., New Delhi.

Sanyal, S. K., Dwivedi, B. S., Singh, V. K., Majumdar, K., Datta, S. C., Pattanayak, S. K. and Annapurna, K. 2015. Phosphorus in relation to dominant cropping sequences in India: chemistry, fertility relations and management options. Curr. Sci., 108(7): 1262 1270.

Sarkar, S., Datta, S. C. and Biswas, D. R. 2013.Using nanoclay polymer composite for efficient delivery of $\mathrm{N}$ and $\mathrm{P}$ to pearl millet grown in a smectite dominant soil in a green house experiment. Clay Res., 32(2): 102-113.

Shrivastava, S., Tomar, P. S., Arya, V. and Verma, S. K. 2017. Effect of integrated application of inorganic and organic sources on soil properties, yield and nutrient uptake by pearl millet. Int. $Q$. J. Life Sci., 12(1): 609-614.

Singh, L., Sharma, P. K., Deewan, P. and Verma, R. 2017. Effect of phosphorus and zinc fertilization on production potential and physico-chemical properties of soil under pearlmillet in semi-arid eastern plain zone of India. Int. J. Chem. Studies, 5(5): 373-376.

Soliman, A. S., Hassan, M., Elella, F. A., Ahmed, A. H. H. and Feky, S. A. E. 2016. Effect of nano and molecular phosphorus fertilizers on growth and chemical composition of baobab (Adansonia digitata L.). J. Plant Sci., 11(4): $52-60$.

Subbaiah, B. V. and Asija, G. L. 1956. A rapid procedure for the determination of available N in soils. Curr. Sci., 25: 259260.

Togas, R., Yadav, L. R., Choudhary, S. L. and Shisuvinahalli, G. V. 2017. Effect of integrated use of fertilizer and manures on growth, yield and quality of pearl millet. Int. J. Curr. Microbiol. Appl. Sci., 6(8): 2510-2516.

Valluru, R., Rizvi, R., Hash, C. T. and Vadez, V. 2008. Efficient microdosing of phosphorus to pearl millet hybrids (Pennisetum americanum L.) for improved seedling establishment under nutrient-stressed environments. Res. Gate, 45: 669-682.

Van, S. N., Minh, H. D. and Anh, D. N. 2013. Study on chitosan nanoparticles on biophysical characteristics and growth of Robusta coffee in green house. Biocatal. Agric. Biotechnol., 2: 289-294.

Veronica, N., Guru, T., Thatikunta, R. and Reddy, N. S. 2015. Role of nano fertilizers in agricultural farming. Int. J. Environ. Sci. Tech., 1(1): 1-3.

\section{How to cite this article:}

Atul Dhansil, N.M. Zalawadia, Bhawani Singh Prajapat and Kamlesh Yadav. 2018. Effect of Nano Phosphatic Fertilizer on Nutrient Content and Uptake by Pearl Millet (Pennisetum glaucum L.) Crop. Int.J.Curr.Microbiol.App.Sci. 7(12): 2327-2337. doi: https://doi.org/10.20546/ijcmas.2018.712.264 